\title{
Maturation and Death of Adult-Born Olfactory Bulb Granule Neurons: Role of Olfaction
}

\author{
Leopoldo Petreanu ${ }^{1}$ and Arturo Alvarez-Buylla ${ }^{2}$ \\ 1 The Rockefeller University, New York, New York 10021, and 2Neurosurgery Research, University of California, \\ San Francisco, San Francisco, California 94134
}

\begin{abstract}
Young neurons born in the subventricular zone (SVZ) of adult mice migrate to the olfactory bulb $(\mathrm{OB})$ where they differentiate into granule cells (GCs) and periglomerular interneurons. Using retroviral labeling of precursors in the SVZ, we describe five stages and the timing for the maturation of newly formed GCs: (1) tangentially migrating neuroblasts (days 2-7); (2) radially migrating young neurons (days 5-7); (3) GCs with a simple unbranched dendrite that does not extend beyond the mitral cell layer (days 9-13); (4) GCs with a nonspiny branched dendrite in the external plexiform layer (days 11-22); and (5) mature GCs (days 15-30). Using $\left[{ }^{3} \mathrm{H}\right]$ thymidine, we show that the maximum number of labeled GCs is observed around day 15 after injection. Interestingly, between days 15 and 45 after birth, soon after the cells developed spines, the number of
\end{abstract}

$\left[{ }^{3} \mathrm{H}\right]$ thymidine-labeled GCs declined by $50 \%$. Using anosmic mice, we found that sensory input was critical for the survival of GCs from day 15 to 45 after labeling. However, the number and morphology of 15-d-old cells in the granule cell layer was similar in anosmic and wild-type mice. We infer that the lack of activity did not have an effect on the generation, migration, and early differentiation of granule cells. Soon after young GCs matured, and presumably became synaptically connected, their survival depended on the level of activity that they received. This selection mechanism might allow the construction of specific OB circuits based on olfactory experience and suggests possible functions of $\mathrm{OB}$ cell replacement.

Key words: olfactory bulb; granule cells; neurogenesis; new neurons; cell death; olfaction
Neurogenesis persists in two regions of the adult mammalian brain: the hippocampus and the olfactory bulb (OB) (Altman, 1969; Lois and Alvarez-Buylla, 1994; Gage, 2000). The adultgenerated neurons of the $\mathrm{OB}$ are born in the subventricular zone (SVZ) (Luskin, 1993; Lois and Alvarez-Buylla, 1994) and migrate along a network of pathways (Doetsch and Alvarez-Buylla, 1996) into the rostral migratory stream (RMS) and into the OB where they differentiate into granule cells (GCs) and periglomerular cells. Most of the OB granule neurons are generated postnatally and continue to be added in adulthood (Kaplan and Hinds, 1977; Bayer, 1983).

Because apoptosis is observed in the layers where the newly generated cells are incorporated (Najbauer and Leon, 1995; Fiske and Brunjes, 2001) and the volume of the OB does not increase in adult mice (Pomeroy et al., 1990), newly generated GCs are thought to replace older cells. Less than $10 \%$ of the GCs born in young adult rats survive 21 months, suggesting that many of these cells have been replaced (Kaplan et al., 1985).

Granule cell bodies cluster, forming sheets in the granule cell layer (GCL). They extend a few short neurites toward deeper parts of the GCL and one large dendrite toward the external plexiform layer (EPL) (Shepherd, 1972; Greer, 1987; Shipley and Ennis, 1996) where it branches extensively. Granule neurons have

\footnotetext{
Received Nov. 28, 2001; revised April 15, 2002; accepted April 19, 2002.

This work was supported by National Institutes of Health Grant HD32116. We thank B. Haripal for technical assistance, D. Vicario for advice on statistical analysis, F. Doetsch, B. Alvarez-Borda, and L. Wilbrecht for helpful comments on this manuscript, A. Newman for assistance in the preparation of this manuscript, and F. Nottebohm for inspiring discussions and support.

Correspondence should be addressed to Arturo Alvarez-Buylla, Neurosurgery Research, Box 0520, 10 Kirkham Street K-27, University of California, San Francisco, San Francisco, CA 94134. E-mail: abuylla@itsa.ucsf.edu.

Copyright (C) 2002 Society for Neuroscience $\quad 0270-6474 / 02 / 226106-08 \$ 15.00 / 0$
}

no axons, and their output is mediated by bidirectional dendrodendritic synapses located in spines (Jahr and Nicoll, 1982; Woolf et al., 1991). GCs are thought to modulate the activity of mitral (M) and tufted (T) cells, optimizing olfactory function by reducing overlap for odor representation by $\mathrm{M}$ and $\mathrm{T}$ cells (Mori and Shepherd, 1994; Yokoi et al., 1995; Hildebrand and Shepherd, 1997). The function of olfactory granule neuron replacement in the adult brain is not known. It has been suggested that this process may be used for plasticity and olfactory discrimination (Gheusi et al., 2000; Cecchi et al., 2001).

Although newly generated cells in adult mice are known to populate the GCL at $\sim 12 \mathrm{~d}$ after they are born in the SVZ (Lois and Alvarez-Buylla, 1994), little is known about the timing of differentiation and death of the newly formed neurons. Defining the different stages of maturation and times when newly formed olfactory interneurons die is required to understand how neuronal replacement in the $\mathrm{OB}$ is regulated. Changes in the morphology of the cells as they migrate along the RMS and invade the bulb have been described using the Golgi method (Kishi, 1987), but the time course of this process in the adult OB is not known. Using retroviral labeling of the newly born neurons in the SVZ, we describe the stages of maturation of newly generated GCs in adult mice. We also identify an early wave of cell death that occurs shortly after the newly formed cells develop their dendritic arbors and synaptic gemmules. Using anosmic mice, we show that GC survival during this period of fast cell death is dependent on incoming activity from the olfactory epithelium.

\section{MATERIALS AND METHODS}

Animals. Two-month-old CD-1 male mice were obtained from Charles River Laboratories (Wilmington, MA). Animals were housed in groups of five per cage, under a $12 \mathrm{hr}$ light/dark cycle (lights on at 8:00 A.M.) with food and water available ad libitum. 
Olfactory cyclic nucleotide gated channel knock-out mice (Brunet et al., 1996) were bred in-house. Heterozygous females were bred with C57BL/6 males to obtain hemizygous mutant males. Most of the mutants died of starvation soon after birth; however, by reducing litters to four pups $24 \mathrm{hr}$ after birth, 4 of 60 mutants managed to survive to adulthood (Baker et al., 1999; Zheng et al., 2000). DNA was extracted from the animals' tails and screened for the mutation by PCR as described (Zheng et al., 2000). Control animals were male littermates. All of the animal procedures were approved by The Rockefeller University's Animal Care and Use Committee.

${ }^{3}$ H-thymidine and bromodeoxyuridine labeling and tissue processing. Forty-five CD-1 animals were injected intraperitoneally with $50 \mu \mathrm{l}$ of $\left[{ }^{3} \mathrm{H}\right]$ thymidine $(6.7 \mathrm{Ci} / \mathrm{mmol}, 1 \mathrm{mCi} / \mathrm{ml}$; New England Nuclear, Boston, MA) every $24 \mathrm{hr}$ for 4 consecutive days. At each of the different survival times, five of the animals were killed by an overdose of pentobarbital (140 $\mathrm{mg} / \mathrm{kg}$ body weight, i.p.). Olfactory cyclic nucleotide gated channel knock-out mice and control littermates were injected once daily for 2 consecutives days with bromodeoxyuridine (BrdU; $50 \mathrm{mg} / \mathrm{kg}$ ) (Sigma, St. Louis, MO). One month later they received a single injection of $50 \mu \mathrm{l}$ of $\left[{ }^{3} \mathrm{H}\right.$ ]thymidine $(6.7 \mathrm{Ci} / \mathrm{mmol}, 1 \mathrm{mCi} / \mathrm{ml})$, and $15 \mathrm{~d}$ later were killed by an overdose of pentobarbital. All of the animals received the injections between 2 and 4 P.M. Animals were intracardially perfused with $0.9 \%$ $\mathrm{NaCl}$, followed by $3.0 \%$ paraformaldehyde (PFA), and the brains were postfixed overnight in the same fixative. Brains were embedded in polyethyleneglycol (PEG) and sectioned coronally at $6 \mu \mathrm{m}$ (Alvarez-Buylla et al., 1988). Serial sections $120 \mu \mathrm{m}$ apart from the whole olfactory bulb were mounted. Olfactory bulbs from CD-1 mice were processed for Nissl staining or NeuN immunochemistry followed by autoradiography. Sections from anosmic mice and control littermates were processed for autoradiography, terminal deoxynucleotidyl transferase-mediated biotinylated UTP nick end labeling (TUNEL), BrdU, and Nissl staining.

NeuN immunochemistry. PEG sections $(6 \mu \mathrm{m})$ were incubated with $3 \%$ $\mathrm{H}_{2} \mathrm{O}_{2}$ in methanol for $15 \mathrm{~min}$ and then for $48 \mathrm{hr}$ at $4^{\circ} \mathrm{C}$ with NeuN monoclonal antibody (1:200; Chemicon, Temecula, CA). Slides were then incubated in biotinylated mouse secondary antisera (1:200; Vector Laboratories, Burlingame, CA) for $60 \mathrm{~min}$ (room temperature), rinsed, incubated in avidin-biotin-horseradish peroxidase (AB; 1:200; Vector Laboratories) for $30 \mathrm{~min}$, and in $0.02 \%$ diaminobenzidine (DAB) with $0.003 \%$ $\mathrm{H}_{2} \mathrm{O}_{2}$ for 5 min.

TUNEL technique staining. Apoptotic cell death was detected in $6 \mu \mathrm{m}$ PEG sections using the TUNEL staining method (Gavrieli et al., 1992; Holcomb et al., 1995) and visualized using AB (1:200; Vector Laboratories) for $30 \mathrm{~min}$ followed by $5 \mathrm{~min}$ in $0.02 \% \mathrm{DAB}$ with $0.003 \% \mathrm{H}_{2} \mathrm{O}_{2}$.

Retrovirus microinjection and tissue processing. Replication-incompetent retroviruses encoding the marker gene human placental alkaline phosphatase (DAP) were harvested from the psi2 DAP cell line (American Type Cell Culture 1949-CRL) (Fields-Berry et al., 1992), concentrated, titered, and tested for helper virus (Cepko, 1992). The titer was $10^{8}$ colony-forming units $/ \mathrm{ml}$.

Each animal was injected stereotaxically with $0.2 \mu \mathrm{l}$ of retrovirus in two coordinates for each hemisphere (relative to bregma: anterior, 1; lateral, \pm 1 ; depth, 2.2; and anterior, 0; lateral, \pm 1.4 ; depth, 1.6). At different survival times, the animals were killed by an overdose of anesthesia (pentobarbital, $140 \mathrm{mg} / \mathrm{kg}$ ). Animals were perfused intracardially with $30 \mathrm{ml}$ of $0.9 \%$ saline followed by $30 \mathrm{ml} 3 \%$ PFA. The brain was extracted and fixed overnight in the same fixative. The olfactory bulbs were cut horizontally in $60 \mu \mathrm{m}$ serial sections using a vibratome and processed for alkaline phosphatase histochemistry as described (FieldsBerry et al., 1992).

Image analysis and quantification. Cell counts and area measurements were performed using a computer-based mapping microscope (AlvarezBuylla and Vicario, 1988). For each OB section, the area of the granule cell layer was measured by subtracting the area of the RMS and the accessory olfactory bulb from the area delimited by the mitral cell layer. The area of the RMS in coronal sections, from the rostral tip of the lateral ventricle to the rostral end of the OB, was measured in Nisslstained sections. The RMS is easily distinguishable from surrounding tissue because of its higher cell density. Areas were measured in $6-\mu \mathrm{m}-$ thick serial sections at $120 \mu \mathrm{m}$ intervals. The volumes of the granule cell layer and the RMS were approximated with the equation:

$$
\sum_{i=0}^{n} A_{\mathrm{i}} d
$$

where $A$ equals the area of the i-th section, $d$ is the distance between traced sections, and $n$ is the total number of measured sections. The density of NeuN-labeled cells per unit area was measured in five fields (400× magnification) in the granule cell layer. The number of $\left[{ }^{3} \mathrm{H}\right]$ thymidine-, BrdU-, or TUNEL-labeled nuclei was counted in the entire GCL of two sections, 120 and $600 \mu \mathrm{m}$ rostral to the accessory olfactory bulb. Neurons were considered to be labeled if they had over their nuclei $10 \times$, or greater, the number of exposed silver grains compared with background. In anosmic and control littermates, the number of silver grains was counted on $200\left[{ }^{3} \mathrm{H}\right]$ thymidine-labeled cells for each group.

Total numbers of $\left[{ }^{3} \mathrm{H}\right]$ thymidine- and BrdU-labeled cells in the $\mathrm{OB}$ were estimated counting nuclear profiles. Given the size range of granule cell nuclei, it is not necessary to correct for cell splitting between $6 \mu \mathrm{m}$ sections for $\left[{ }^{3} \mathrm{H}\right]$ thymidine-labeled nuclei (Clark et al., 1990). Therefore, the total number of $\left[{ }^{3} \mathrm{H}\right]$ thymidine-labeled cells was estimated using the formula: $T=(N \times V) / t$, where $T$ is the total number of cells, $N$ is the number granule cell nuclei per unit area, $V$ is the volume of the granule cell layer, and $t$ is the section thickness. To derive total numbers of BrdU-labeled cells, a cell splitting correction factor based on the Abercrombie method (Guillery and Herrup, 1997) was used. The total number of BrdU cells was calculated using the formula $T=(N \times V) /(t+D)$, where $D$ is the average diameter of BrdU-labeled nuclei. Granule cell diameters from 250 cells per group were measured from photomicrographs of the GCL using NIH Image. No difference in cell diameter was found between anosmic and control mice. Note that absolute estimates of number of cells in the OB allow for comparisons between experimental groups within this study, but that these numbers are limited by the sampling methods and assumptions of the Abercrombie correction. $\left[{ }^{3} \mathrm{H}\right]$ thymidine autoradiography in $6-\mu \mathrm{m}$-thick sections allows for high histological resolution, but unbiased stereological methods are not possible in this material (Clark et al., 1990).

\section{RESULTS}

\section{Maturation of adult-generated granule neurons}

To study the time course of the development of newly generated granule neurons, we injected the SVZ with a replication incompetent retrovirus encoding the human placental alkaline phosphatase (Fields-Berry et al., 1992). Five days after injection, DAP-labeled cells were localized along the RMS and in the core of the olfactory bulb. Staining was seen over the entire surface of the membrane of each cell, revealing its morphology with fine detail (Fig. 1) (Doetsch et al., 1999).

Five and $7 \mathrm{~d}$ after viral injection, the majority of cells had the typical morphology of migrating neuroblasts (class 1) (Fig. 1A$C)$. This morphology has been described in detail previously (Kishi, 1987; Lois et al., 1996; Wichterle et al., 1997). Class 1 cells had a round or elongated cell body with a prominent leading process and growth cone, and occasionally a small trailing process. These cells were found only in the RMS and its rostral extension in the core of the OB. Cells with their growth cone oriented either rostrally (58 $\pm 5 \% ; n=2 ; 91$ cells) or caudally $(42 \pm 5 \%)$ were found in the core of the OB. This suggests that migrating precursors in the core of the $\mathrm{OB}$ move in both directions. With longer survivals, many of the young migrating neurons were found farther away from the $\mathrm{OB}$, migrating radially toward more superficial layers. These cells maintained their elongated morphology, but their leading and trailing processes were longer. The leading process was frequently bifurcated with multiple, small ramifications (class 2) (Fig. $1 D-F$ ). The growth cone of class 2 cells was less prominent than that of class 1 cells. Beginning at day 9 after injection, a third class of DAP-labeled cells was observed. These cells had a larger, rounder cell body, with a prominent single process that extended toward the EPL, but did not cross the mitral cell layer (class 3) (Fig. 1G-I). We infer that this process corresponds to the growing apical dendrite. The smooth trailing process observed in class 1 and 2 cells was not 


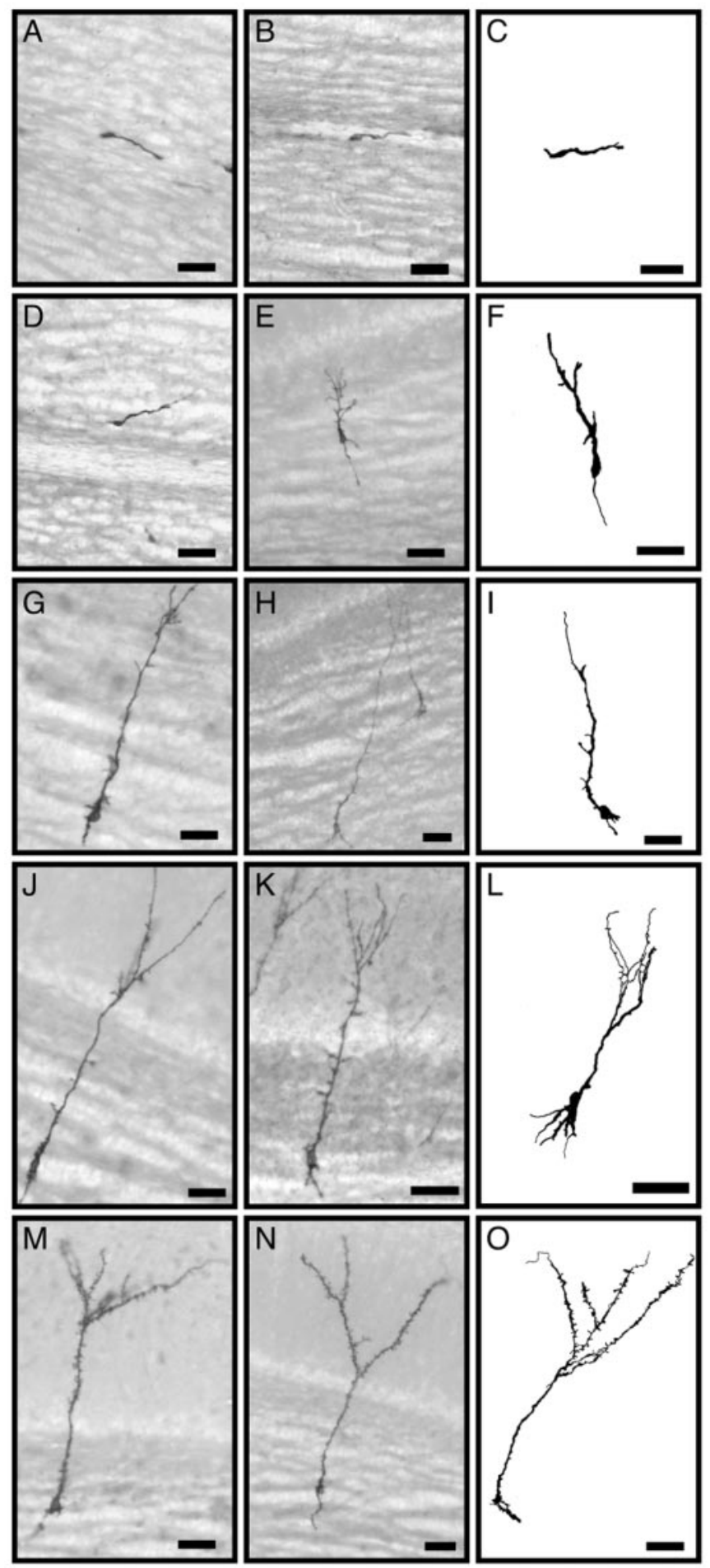

Figure 1. Alkaline phosphatase staining of virus-infected newly generated cells in the GCL of the olfactory bulb. Photomicrographs (left and center columns) and camera lucida drawings (right column) show examples of stained developing granule neurons at different maturation stages as defined in Results: class $1(A-C)$; class $2(D-F)$; class $3(G-I)$; class 4 $(J-L)$; class $5(M-O)$. Scale bars, $25 \mu \mathrm{m}$.

observed in class 3 cells. Instead, these cells had neurites developing on the basal side, extending into the neighboring GCL, probably corresponding to the developing basal dendrites. In contrast to the smooth contours of class 1 and 2 cells, class 3 cells

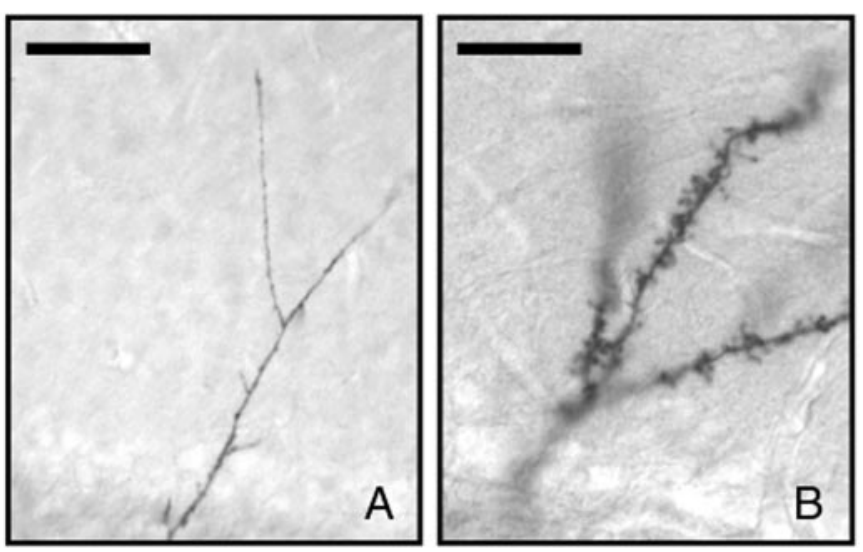

Figure 2. Alkaline phosphatase staining of the dendritic arbors of virusinfected newly generated cells in EPL of the olfactory bulb. Representative photomicrographs show the dendritic arborization of developing granule neurons at early stages of maturation $(A)$ and at later stages, after developing dendritic spines $(B)$. Scale bars, $25 \mu \mathrm{m}$.

had irregular borders with varicosities around the cell body and in the developing basal dendrites (Fig. $1 G-I$ ). The cell bodies of class 3 cells were aligned with clusters of other resident granule neurons. The morphology and location of class 3 cells suggested that they had completed their migration, and their cell bodies had become settled in a particular location next to other granule neurons.

At later time points, cells grew dendrites that extended beyond the mitral cell layer and branched in the EPL. We subdivided these cells into two classes (class 4 and class 5). Class 4 cells had elaborate branched apical dendrites (Fig. $1 J-L$ ), but had few, if any, spines (Fig. 2A). The size and shape of the basal processes and soma were similar to that of class 3 cells. Class 5 cells (Fig. $1 M-O)$, in addition to the elaborate branched apical dendrites, had many spines (gemmules) at high density on the apical dendrites (Fig. 2B).

To determine the order of appearance of the different cell types as defined above, mice were killed at eight different survival points, and the number of cells of each type was quantified (Fig. 3). Class 1 cells were found in the core of the OB between days 5 and 9 , and thereafter their number decreased. This indicates that the progeny of virally infected cells in the SVZ arrived at the bulb as a bolus of young neurons, and that by day 9 most of the new neurons had left the RMS. This is consistent with previous work indicating that most of the cells labeled by a single injection of an $\mathrm{S}$ phase marker correspond to the young neuroblasts and the actively dividing transit amplifying precursors, not the stem cells (Doetsch et al., 1997). By day 9, a few cells had already developed elaborate dendritic arbors (class 4), but most of the cells at this time were migrating radially (class 2 ). Within the next $4 \mathrm{~d}$ (days 9-13), there was a very rapid maturation of the dendritic fields, but cells had relatively few spines. By day 13 the majority of labeled cells corresponded to class 4 . This changed dramatically in the subsequent $2 \mathrm{~d}$. By day 15 most of the labeled cells had developed many spines, and by day 22 the majority of the labeled cells corresponded to class 5 . This suggests that the majority of synaptic contacts on spines of the newly formed neurons developed between days 13 and 22. By day 30 all of the labeled cells had developed branched apical dendrites, and most of them had many spines. This indicates that within a week the cells moved from the core of the $\mathrm{OB}$ to the superficial layer and 


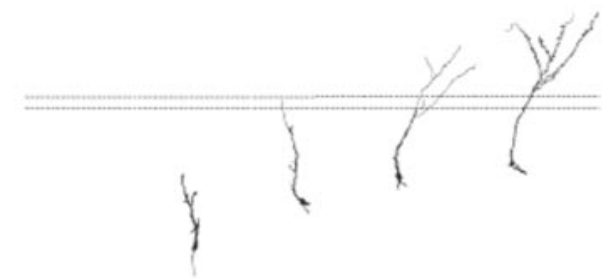

EPL

MCL

GCL

Class 1 Class 2 Class 3 Class 4 Class 5

RMS

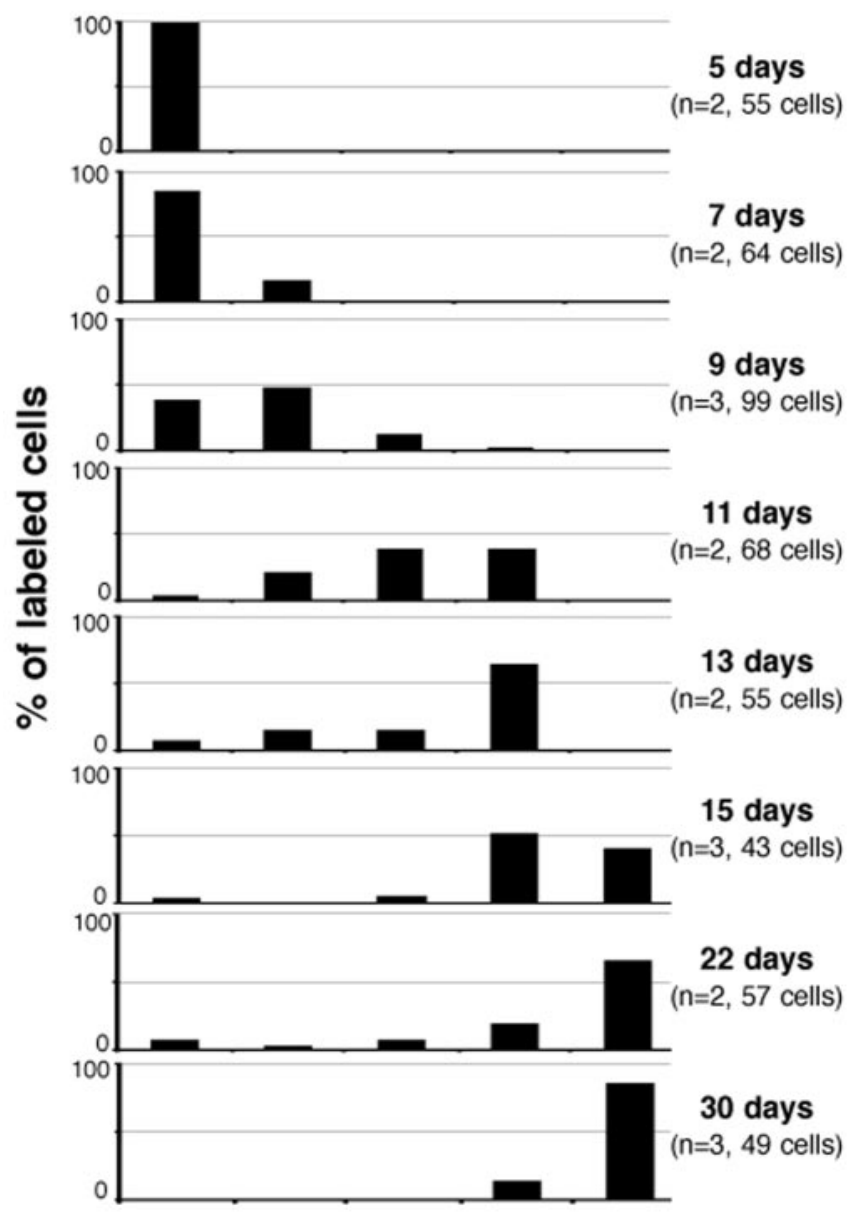

Figure 3. Time course of the development of adult-generated olfactory bulb granule neurons. Percentage of alkaline phosphatase-labeled cells in the GCL of the olfactory bulb belonging to each of the developing stages defined in Results (Fig. 1) at different survival times. Top diagram indicates an example of each morphological class. EPL, External plexiform layer; $M C L$, mitral cell layer; $G C L$, granule cell layer; $R M S$, rostral migratory stream.

developed their mature morphology. No cells with other morphologies besides those described above were observed in the RMS and the GCL.

\section{Population dynamics of the incorporation of adult generated granule neurons}

Although the viral injections allowed us to determine the morphology of the newly formed cells in the OB, it did not allow for a quantitative estimation of the absolute number of new neurons recruited into the bulb. To determine total new granule cells incorporated into the adult olfactory bulb, mice were injected with $\left[{ }^{3} \mathrm{H}\right]$ thymidine, and labeled cells in the GCL were quantified at different survival times. As seen in Figure $4 B$, the number of
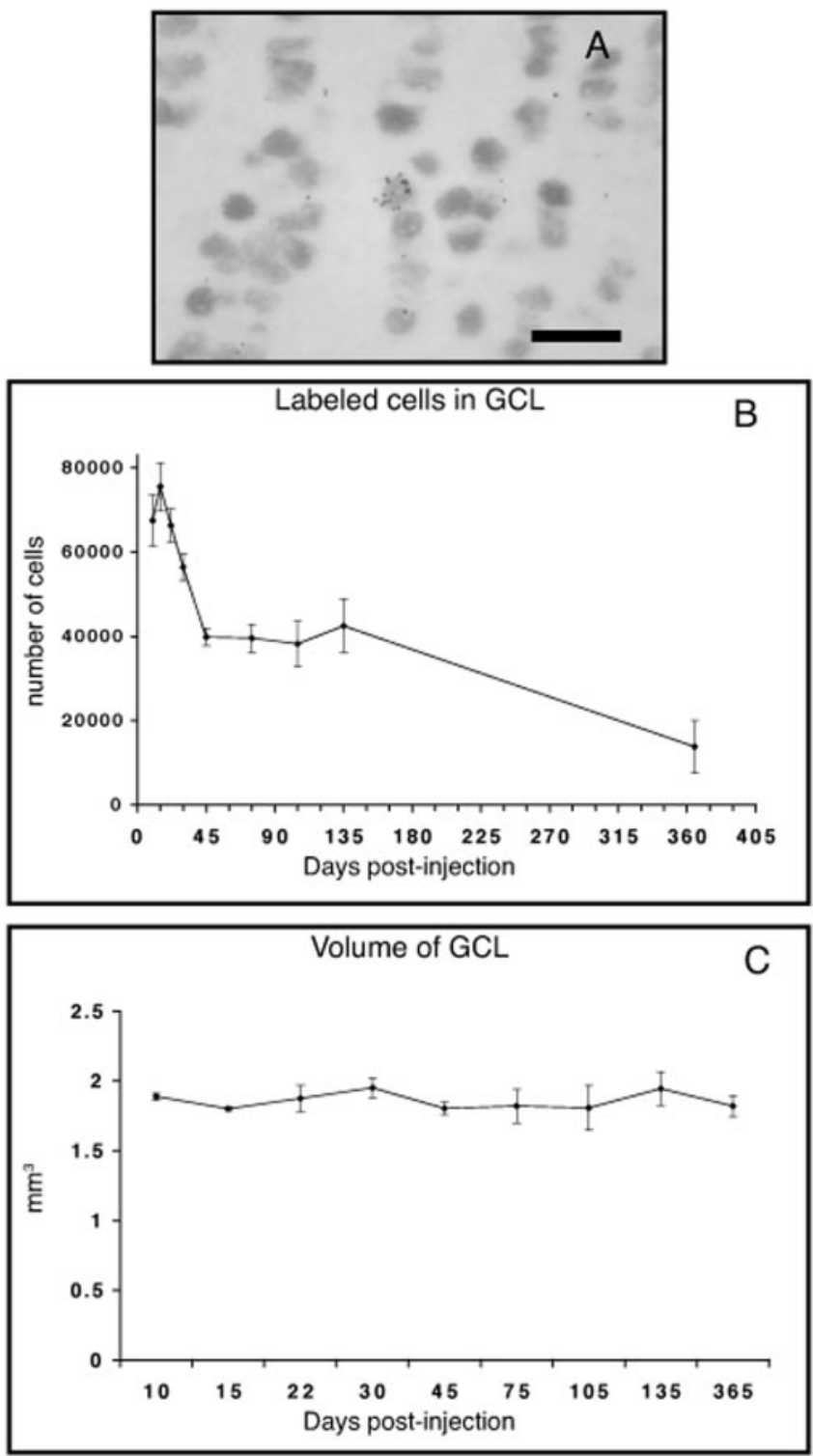

Figure 4. Labeled cells in the GCL of the olfactory bulb at different survival points after $\left[{ }^{3} \mathrm{H}\right]$ thymidine injection. $A$, Photomicrograph of a $\left[{ }^{3} \mathrm{H}\right]$ thymidine-positive, NeuN-positive cell in the GCL. Scale bar, $20 \mu \mathrm{m}$. $B$, The number of $\left[{ }^{3} \mathrm{H}\right]$ thymidine-labeled cells in the GCL at different survival times. $C$, The volume of the GCL at different survival times. Values indicate mean $\pm \mathrm{SE}$.

labeled cells in the granule cell layer increased nonsignificantly from days 10 to 15 after injection (Newman-Keuls test; $p>0.25$ ) and declined thereafter. Labeled cells were seen up to 1 year later, showing that some newly generated cells can live at least this long in the OB. Interestingly, however, between days 15 and 45 after injection there was a sharp decline in the number of newly formed neurons observed in the granule cell layer, with the number of labeled cells reduced by one-half (Newman-Keuls test; $p<0.001)$. After $45 \mathrm{~d}$, the number of labeled cells stabilized (Fig. $4 B$ ), and their number did not differ significantly during the following 3 months (Newman-Keuls test; $p>0.05)$ ). After 1 year, one-third of these surviving cells were still found in the GCL. These results identify an early wave of cell death soon after newly generated cells mature and develop synaptic spines. The more gradual decline that occurs 3 months after cell birth might be 


\begin{tabular}{|c|c|c|}
\hline $\begin{array}{l}\text { Days after } \\
\text { injection }\end{array}$ & $\begin{array}{l}\% \text { of labeled cells } \\
\text { NeuN }+\end{array}$ & $\begin{array}{l}\% \text { of NeuN }+ \text { cells } \\
\text { labeled }\end{array}$ \\
\hline 15 & $68.8 \pm 2.3$ & $2.2 \pm 0.07$ \\
\hline 22 & $80.2 \pm 3.8$ & $2.1 \pm 0.04$ \\
\hline 30 & $81.2 \pm 2$ & $1.7 \pm 0.13$ \\
\hline 45 & $84.1 \pm 3.9$ & $1.5 \pm 0.03$ \\
\hline 75 & $84.3 \pm 1$ & $1.4 \pm 0.11$ \\
\hline 365 & $81.9 \pm 3.2$ & $0.3 \pm 0.07$ \\
\hline
\end{tabular}

Values are \pm SEM.

related to the rate of neuronal replacement in the GC layer. Very few cells were seen in the RMS after $15 \mathrm{~d}$ (data no shown). It is therefore unlikely that the arrival of new cohorts of labeled cells from secondary stem cell division contributes to the plateau of cell survival. This is consistent with evidence that very few long-term renewing stem cells get labeled in the SVZ after proliferation marker injections (Morshead et al., 1994; Doetsch et al., 1997). As seen in Table 1, double labeling of the newly generated cells with the neuronal marker NeuN showed that at least $84 \%$ of the new cells become neurons. The remaining $16 \%$ could correspond to astrocytes or microglia, or neurons that express NeuN at levels below the sensitivity of the method. The four injections of $\left[{ }^{3} \mathrm{H}\right]$ thymidine given to the animals resulted in $2.2 \%$ labeled NeuN-positive granule neurons at $15 \mathrm{~d}$ and $1.5 \%$ at $45 \mathrm{~d}$ (Table 1).

\section{Granule cell incorporation and survival in anosmic mice}

The above analysis indicated that between 15 and $22 \mathrm{~d}$ after birth, newly generated granule cells show a mature morphology. These results suggest that during the early wave of cell death, granule neurons already receive connections from the $\mathrm{M}$ and $\mathrm{T}$ cells. Activity through $\mathrm{M}$ and $\mathrm{T}$ cells may regulate the survival of newly incorporated neurons during this period. To test whether olfactory input has a role in the regulation of granule cell death, we analyzed the dynamics of granule cell incorporation in adult anosmic mice. Animals that have a mutation in the olfactory cyclic nucleotide gated channel are not able to transduce the signal from olfactory receptors in olfactory receptor neurons. These animals lack all electrical activity in the olfactory epithelium and do not have electrical input into the olfactory bulb (Brunet et al., 1996; Zhao and Reed, 2001). These mice have small olfactory bulbs (Baker et al., 1999), suggesting that granule cells might be dying. In coronal sections of the $O B$, the area occupied by the rostral end of the RMS in the core of the OB was larger than that seen in wild-type mice (Fig. 5A,B). However, because the $\mathrm{OB}$ is much smaller in the mutant mice, the volume of the RMS measured from the frontal tip of the lateral ventricles to the rostral end of the OB did not differ significantly (Student's $t$ test; $p>0.2$ ) in the two groups (anosmic: $0.035 \pm 0.011 \mathrm{~mm}^{3}$; control: $0.044 \pm 0.007 \mathrm{~mm}^{3}$ ). These results indicate that despite the lack of activity and the smaller GCL, the RMS is not significantly affected, suggesting that many new neurons migrate along the RMS and arrive in the core of the OB of the mutant mice.

Using TUNEL staining, we detected significantly higher levels of apoptotic cell death in the granule cell layer in the anosmic mice compared with littermate controls (Fig. 5D-F). To test whether granule cells in anosmic animals were dying before or after they developed their mature morphology, animals were injected with BrdU at day 0 and with $\left[{ }^{3} \mathrm{H}\right]$ thymidine at day 30 and were perfused at day 45 . BrdU immunostaining and $\left[{ }^{3} \mathrm{H}\right]$ thymidine autoradiography revealed granule cells that were 45 and $15 \mathrm{~d}$ old, respectively. The number of 15-d-old cells in the granule cell layer was slightly decreased in mutant mice but not significantly different when compared with control mice (Fig. 6D). This resulted in a twofold higher density of 15 -d-old $\left[{ }^{3} \mathrm{H}\right]$ thymidinelabeled cells in the GCL (data not shown) of the mutant mice compared with controls because the volume of this layer is reduced by half in the mutants. However, the total number of 45-day-old granule cells was reduced four times in mutant mice compared with controls (Fig. 6D), showing that most of the granule cells of the anosmic animals died between 15 and $45 \mathrm{~d}$ after birth.

To determine whether cell division during migration (Lois and Alvarez-Buylla, 1994; Menezes et al., 1995) was affected by incoming activity, we counted the number of silver grains in the $\left[{ }^{3} \mathrm{H}\right]$ thymidine-labeled cells from both groups. We found no significant difference (Student's $t$ test; $p>0.5$ ) between the anosmic (mean $21.52 \pm 14.32$ grains per labeled cells) and the control littermates $(22.4 \pm 15$ grains per labeled cells). It was possible that the new granule cells in the anosmic animals failed to mature normally and that this resulted in lower survival. Retroviral injections in mutant mice revealed that as with control mice, most of the 15-d-old granule cells in the anosmic mice had dendritic arborization beyond the EPL (classes 4 and 5) (Fig. $6 A-C$ ), and many of these cells had dendritic spines (Fig. $6 B$ ). We conclude that in the anosmic mice, granule cells are produced, migrate, and mature in a manner very similar to those of the wild-type mice. However, after this initial period of maturation, many more granule cells die when olfactory activity is not present.

\section{DISCUSSION}

By using retroviral labeling methods, we were able to describe and time the development and maturation of adult-generated GCs. Most of the adult-generated GCs attain a fully mature morphology between 15 and $30 \mathrm{~d}$ after birth in the SVZ. The morphology of all the cells in the GCL that originated in the SVZ, as determined by the viral injections, corresponded to that of granule neurons. This suggests that cells born in the SVZ that end up in the GCL become only granule neurons. The small proportion $(16 \%)$ of NeuN-negative cells in the $\left[{ }^{3} \mathrm{H}\right]$ thymidine experiment (Table 1) are either glia that are generated locally or neurons that express $\mathrm{NeuN}$ at levels below the sensitivity of the technique used here. The sequence of stages for the development of GCs that we describe here is similar to those observed in earlier postnatal animals using Golgi staining (Kishi, 1987), suggesting that developing granule cells follow a similar maturation process in juvenile and adult animals. In agreement with previous studies in the adult mice (Bayer, 1983; Lois and Alvarez-Buylla, 1994), we also observed a small proportion of periglomerular neurons being formed. Given the proportionally smaller number of periglomerular cells that formed, we did not study this population in detail here.

Fifteen days after four daily injections of $\left[{ }^{3} \mathrm{H}\right]$ thymidine, $2.2 \%$ of the NeuN-positive GCs were found labeled. By $45 \mathrm{~d}$ after $\left[{ }^{3} \mathrm{H}\right]$ thymidine injection, $1.5 \%$ were found labeled. We estimate that $15 \mathrm{~d}$ after 1 month of neurogenesis, $\sim 14 \%$ of the cells in the GCL will be new. This is probably an underestimation because it assumes that with each daily injection all of the neurons born that day were labeled. This is unlikely given that the estimated cell 

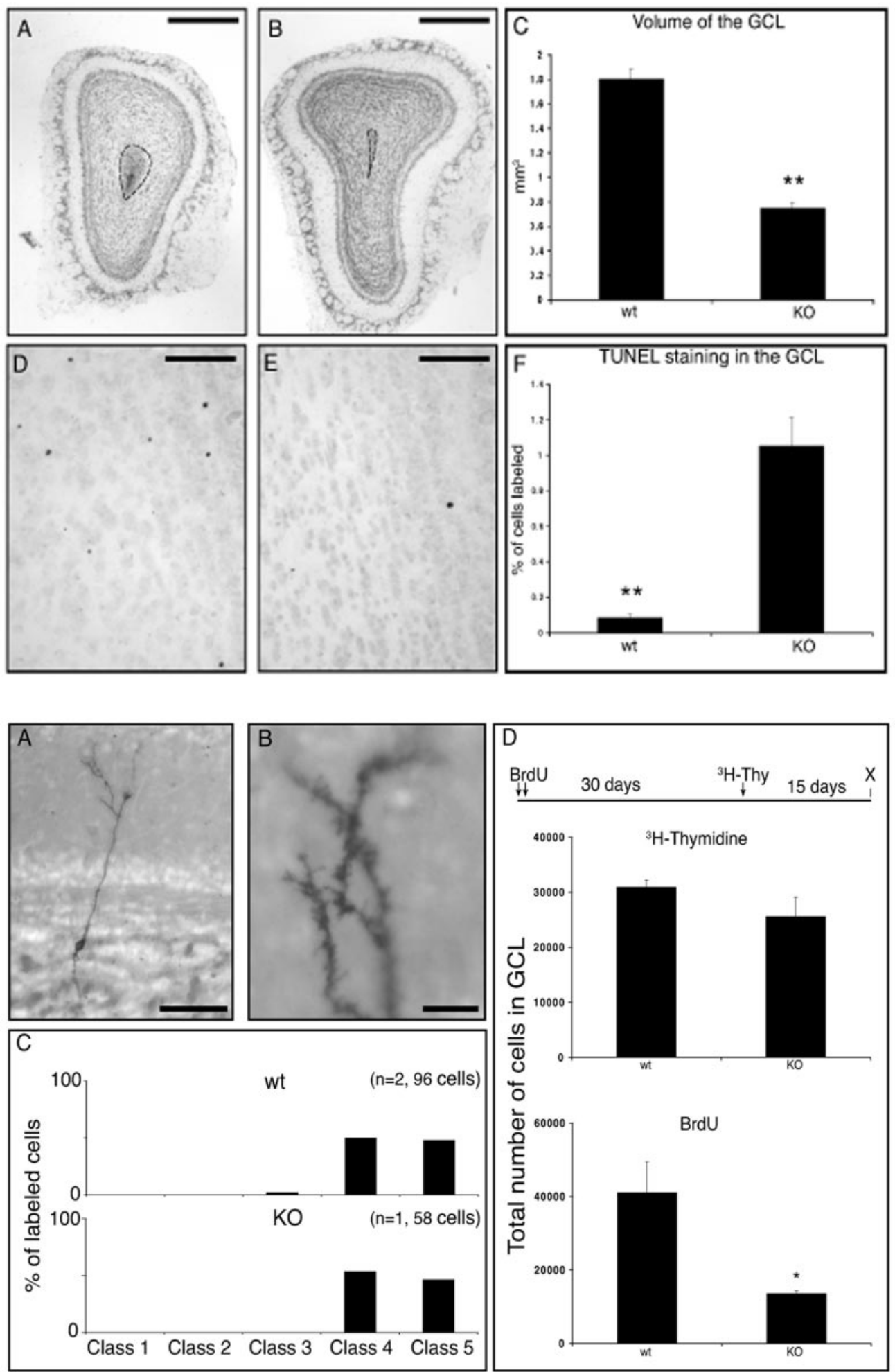

Figure 5. Morphology and cell death in the olfactory bulbs of anosmic mice. Photomicrographs of a Nissl-stained coronal section of the olfactory bulb of an anosmic mouse $(A)$ or a control littermate $(B)$. Dotted lines outline the contour of the RMS. Scale bars, $0.5 \mathrm{~mm}$. $C$, Volume of the GCL in anosmic $(n=3)$ and control mice $(n=4)$. Representative photomicrographs show TUNEL-stained apoptotic cells in the GCL of anosmic $(D)$ and control mice $(E)$. Scale bars, $50 \mu \mathrm{m}$. E, Quantification of TUNEL staining in the GCL of anosmic $(\mathrm{KO})(n=3)$ and control mice $(w t)(n=4)$. Values indicate mean $\pm \mathrm{SE}$. Statistical analysis was conducted by unpaired Student's $t$ test. Significance was established at ${ }^{* *} p<0.01$.

Figure 6. Morphology and cell survival of newly generated cells in the olfactory bulb of anosmic mice. $A$, Photomicrograph of a class 4 cell in the GCL of an anosmic mouse. Several focal planes were combined in Photoshop to reconstruct the cell. Scale bar, $50 \mu \mathrm{m}$. B, Photomicrograph of the dendritic tree of a class 5 cell in the EPL of an anosmic mouse. Scale bar, $20 \mu \mathrm{m}$. $C$, The percentage of cells belonging to each of the five morphological classes in anosmic $(K O)$ and control littermates $(w t) . \mathrm{D}$, Total number of $\left[{ }^{3} \mathrm{H}\right]$ thymidine- and BrdU-labeled cells in the GCL in control $(n=4)$ or anosmic mice $(n=3)$. Statistical analysis was conducted by unpaired Student's $t$ test. Significance was established at $* p<0.05$. Time line represents the injection protocol for the experiment. Arrows indicate injection of either BrdU or $\left[{ }^{3} \mathrm{H}\right]$ thymidine. $X$ indicates time of perfusion. Values indicate mean $\pm \mathrm{SE}$. cycle in the SVZ is likely $<24 \mathrm{hr}$ (Morshead and Van der Kooy, 1992). Such a rate of neuronal replacement might allow for considerable circuit plasticity in the $\mathrm{OB}$, potentially changing the way it processes olfactory information over a relatively short period of time.

We found a sharp decrease in the number of $\left[{ }^{3} \mathrm{H}\right]$ thymidinelabeled granule cells between 15 and $45 \mathrm{~d}$ after $\left[{ }^{3} \mathrm{H}\right]$ thymidine injection, during which approximately one-half of the newly gen- erated cells are lost. After this time point, the number of labeled cells remained constant for several months. The reduction in $\left[{ }^{3} \mathrm{H}\right]$ thymidine-labeled cells is probably caused by cell death and not migration to the glomerular layer, because we have shown with retroviral labeling that during this time window labeled cells have a postmigratory morphology. Because the volume of the GCL (Fig. $4 B$ ) and the GC density (data not shown) were found not to change significantly (ANOVA; $F=0.76$; df $=8,30 ; p>$ 
0.6) during the period studied, the reduction in $\left[{ }^{3} \mathrm{H}\right]$ thymidinelabeled cells cannot be caused by a decrease in the density of labeled cells as a result of an increase in the total number of cells in the GCL. Interestingly, a similar profile of cell death is observed for the adult-generated neurons of the high vocal center of canaries (Kirn et al., 1999), where one-half of the labeled cells died shortly after their arrival into the nucleus.

Cell death seems to be a prominent factor regulating adult neuronal incorporation, perhaps a mechanism similar to that observed during earlier development (Linden, 1994; Katz and Shatz, 1996; Voyvodic, 1996).

Cell death in the embryo is generally thought to function as a mechanism to adjust the size of a neuronal pool to that of its input and target (Oppenheim, 1991). During development, the size of the pool of cells providing the input or serving as the target changes with growth. In the adult olfactory bulb it is relatively stable, because the number of $\mathrm{M}$ and $\mathrm{T}$ cells does not change significantly with time (Hinds and McNelly, 1977). Cell death in the adult may be closely linked to activity and to the functional contribution of specific neurons. The retroviral labeling experiment showed that during this early wave of cell death, between days 15 and 45 after neuronal birth, most of the dying cells had already matured and developed dendritic arborizations. This suggests that before undergoing apoptosis, these new cells became connected to $\mathrm{M}$ and $\mathrm{T}$ cells. It will be important to compare the specific functional characteristics of cells that become connected in the $\mathrm{OB}$ environment but will not survive versus those that will survive for the following $90 \mathrm{~d}$. Our work provides the time window to study the selection process of newly incorporated neurons.

Using anosmic mice, we have shown that during the period of fast cell death, survival is dependent on incoming activity. We have seen that the lack of electrical activity in mutant mice dramatically reduced the survival of the newly generated neurons during this period. Interestingly, the number of labeled cells in the GCL at $15 \mathrm{~d}$ after injection is not significantly reduced in anosmic compared with wild-type mice. Their overall morphology, $15 \mathrm{~d}$ after injection, was also not affected in anosmic mice, suggesting that olfactory activity is not important for the early differentiation of newly generated GCs. In agreement with the present observations, naris closure experiments in postnatal animals have shown that neither GC morphology (Frazier-Cierpial and Brunjes, 1989b) nor cell proliferation (Frazier-Cierpial and Brunjes, 1989a; Cummings et al., 1997) is affected by sensory deprivation. Our results showed that the lack of activity dramatically reduces survival after the cells have become lodged in the GCL, have grown dendritic arborizations covered by spines, and probably have made connections. These results suggest that olfaction plays a critical role only in the survival of cells once they have attained a mature morphology and not in the production, migration, or initial recruitment. As during development, neuronal incorporation and synapse formation might be mediated by an activity-independent mechanism (Ziv and Garner, 2001) that is regulated by endogenous programs within the young neurons. This may be followed by an activity-dependent mechanism in which many cells are eliminated by apoptosis (Verhage et al., 2000).

The fact that the newly generated granule cells are dependent on afferent activity for their survival once they have developed their dendritic arborization and are likely to be connected has interesting consequences for the processing of olfactory information in the olfactory bulb circuitry. GCs may be selected for survival in an activity-dependent manner according to the specific connection that they make with $\mathrm{M}$ and $\mathrm{T}$ cells. The ones that connect active $\mathrm{M}$ and $\mathrm{T}$ cells may be selected to survive and those that connect to inactive cells may be lost. Previous modeling experiments have shown that such an activity-dependent mechanism could potentially redistribute the representation of odorants in the mitral cell layer to maximize the differences between similar odors and therefore increase olfactory discrimination (Cecchi et al., 2001). Granule cells are known to extensively shape mitral cell response to odors (Yokoi et al., 1995), and there is evidence that the $\mathrm{OB}$ circuitry does maximize differences in odor representations (Friedrich and Laurent, 2001). The representation of odorants in the olfactory bulb can thus be renormalized and kept optimal for a changing olfactory environment using such an activity-dependent mechanism. The observation that a reduction in cell migration to the OB hampers olfactory discrimination is consistent with this hypothesis (Gheusi et al., 2000). It is likely that a similar mechanism may be operating since birth. Ninety percent of the granule cells are incorporated postnatally, and their survival is also dependent on incoming activity (Rosselli-Austin and Williams, 1990; Brunjes, 1994). The development of olfactory discrimination and the maintenance of this sensory modality in the adult may depend critically on the selective survival of new neurons on the basis of their level of activity.

It remains a mystery why the olfactory bulb might need cell replacement as a mechanism of plasticity, which in principle seems much more drastic and costly than mechanisms of synaptic modification (Hebb, 1949; Kandel, 1997). This might be related to the unique characteristics of the olfactory system. The OB is the first processing stage of olfactory information, similar to the retina for the visual system (DeVries and Baylor, 1993; Nakanishi, 1995). In the retina, a given photoreceptor activates inhibitory circuits that influence cells around it, producing the centersurround properties of the ganglion cell receptive fields. Unlike vision, olfaction has intrinsic high dimensionality (Hopfield, 1991). As a consequence, in the OB, a given $M$ and $T$ neuron needs an inhibitory network that influences other $\mathrm{M}$ and $\mathrm{T}$ cells, not necessarily physically around them but in the more complex olfactory space (Galizia and Menzel, 2000; Sachse and Galizia, 2002). That usually means that groups of $M$ and $T$ cells far away from each other may need to be linked by inhibitory connections. Coactivation of glomeruli that respond to a single odor cannot be predicted on the basis of the physical position of one with respect to the other (Kauer and White, 2001). Thus, unlike other sensory systems, it might not be feasible to preassemble a unique inhibitory circuit that processes olfactory information optimally for all the possible odors that an animal might experience during development and in adult life. Therefore, it might be necessary to build the inhibitory circuit of the $\mathrm{OB}$ according to experience by the activity-dependent survival mechanism described here.

By building the inhibitory circuit postnatally, an optimal OB can be assembled for the initial olfactory environment of the animal. Because this circuitry is custom built for a given olfactory experience, it might become suboptimal as the odor environment changes. The continuation of interneuron generation and replacement in adult life could reflect the necessity to readapt the $\mathrm{OB}$ to ongoing environmental changes to maintain maximal discrimination.

\section{REFERENCES}

Altman J (1969) Autoradiographic and histological studies of postnatal neurogenesis. IV. Cell proliferation and migration in the anterior 
forebrain, with special reference to persisting neurogenesis in the olfactory bulb. J Comp Neurol 137:433-458.

Alvarez-Buylla A, Vicario DS (1988) Simple microcomputer system for mapping tissue sections with the light microscope. J Neurosci Methods 25:165-173.

Alvarez-Buylla A, Theelen M, Nottebohm F (1988) Mapping of radial glia and of a new cell type in adult canary brain. J Neurosci 8:2707-2712.

Baker H, Cummings DM, Munger SD, Margolis JW, Franzen L, Reed RR, Margolis FL (1999) Targeted deletion of a cyclic nucleotide-gated channel subunit (OCNC1): biochemical and morphological consequences in adult mice. J Neurosci 19:9313-9321.

Bayer SA (1983) ${ }^{3}$ H-thymidine-radiographic studies of neurogenesis in the rat olfactory bulb. Exp Brain Res 50:329-340.

Brunet LJ, Gold GH, Ngai J (1996) General anosmia caused by a targeted disruption of the mouse olfactory cyclic nucleotide-gated cation channel. Neuron 17:681-693.

Brunjes PC (1994) Unilateral naris closure and olfactory system development. Brain Res Rev 19:146-160.

Cecchi GA, Petreanu LT, Alvarez-Buylla A, Magnasco MO (2001) Unsupervised learning in a model of adult neurogenesis. J Comp Neurosci 11:175-182.

Cepko CL (1992) Transduction of genes using retrovirus vectors. In: Current protocols in molecular biology (Ausubel FM, Brent R, Kingston RE, Moore DD, Seidman JG, Smith JA, Struhl K, eds), pp 9.9.1-9.14.13. New York: Wiley.

Clark SJ, Cynx J, Alvarez-Buylla A, O'Loughlin B, Nottebohm F (1990) On variables that affect estimates of the true sizes and densities of radioactively labeled cell nuclei. J Comp Neurol 301:114-122.

Cummings DM, Henning HE, Brunjes PC (1997) Olfactory bulb recovery after early sensory deprivation. J Neurosci 17:7433-7440.

DeVries SH, Baylor DA (1993) Synaptic circuitry of the retina and olfactory bulb. Cell [Suppl] 72:139-149.

Doetsch F, Alvarez-Buylla A (1996) Network of tangential pathways for neuronal migration in adult mammalian brain. Proc Natl Acad Sci USA 93:14895-14900.

Doetsch F, Garcia-Verdugo JM, Alvarez-Buylla A (1997) Cellular composition and three-dimensional organization of the subventricular germinal zone in the adult mammalian brain. J Neurosci 17:5046-5061.

Doetsch F, Caille I, Lim DA, García-Verdugo JM, Alvarez-Buylla A (1999) Subventricular zone astrocytes are neural stem cells in the adult mammalian brain. Cell 97:1-20.

Fields-Berry SC, Halliday AL, Cepko CL (1992) A recombinant retrovirus encoding alkaline phosphatase confirms clonal boundary assignment in lineage analysis of murine retina. Proc Natl Acad Sci USA 89:693-697.

Fiske BK, Brunjes PC (2001) Cell death in the developing and sensorydeprived rat olfactory bulb. J Comp Neurol 431:311-319

Frazier-Cierpial L, Brunjes PC (1989a) Early postnatal cellular proliferation and survival in the olfactory bulb and rostral migratory stream of normal and unilaterally odor-deprived rats. J Comp Neurol 289:481-492

Frazier-Cierpial LL, Brunjes PC (1989b) Early postnatal differentiation of granule cell dendrites in the olfactory bulbs of normal and unilaterally odor-deprived rats. Brain Res Dev Brain Res 47:129-136.

Friedrich RW, Laurent G (2001) Dynamic optimization of odor representations by slow temporal patterning of mitral cell activity. Science 291:889-894

Gage FH (2000) Mammalian neural stem cells. Science 287:1433-1438.

Galizia CG, Menzel R (2000) Odour perception in honeybees: coding information in glomerular patterns. Curr Opin Neurobiol 10:504-510.

Gavrieli Y, Sherman Y, Ben-Sasson SA (1992) Identification of programmed cell death in situ via specific labeling of nuclear DNA fragmentation. J Cell Biol 119:493-501.

Gheusi G, Cremer H, McLean H, Chazal G, Vincent JD, Lledo PM (2000) Importance of newly generated neurons in the adult olfactory bulb for odor discrimination. Proc Natl Acad Sci USA 97:1823-1828.

Greer CA (1987) Golgi analyses of dendritic organization among denervated olfactory bulb granule cells. J Comp Neurol 257:442-452.

Guillery RW, Herrup K (1997) Quantification without pontification: choosing a method for counting objects in sectioned tissues. J Comp Neurol 386:2-7.

Hebb DO (1949) The organization of behavior: a neuropsychological theory. New York: Wiley.

Hildebrand JG, Shepherd GM (1997) Mechanisms of olfactory discrimination: converging evidence for common principles across phyla. Annu Rev Neurosci 20:595-631.

Hinds JW, McNelly NA (1977) Aging of the rat olfactory bulb: growth and atrophy of constituent layers and changes in size and number of mitral cells. J Comp Neurol 72:345-367.

Holcomb JD, Mumm JS, Calof AL (1995) Apoptosis in the neuronal lineage of the mouse olfactory epithelium: regulation in vivo and in vitro. Dev Biol 172:307-323.
Hopfield JJ (1991) Olfactory computation and object perception. Proc Natl Acad Sci USA 88:6462-6466.

Jahr CE, Nicoll RA (1982) Noradrenergic modulation of dendrodendritic inhibition in the olfactory bulb. Nature 297:227-229.

Kandel ER (1997) Genes, synapses, and long-term memory. J Cell Physiol 173:124-125.

Kaplan MS, Hinds JW (1977) Neurogenesis in the adult rat: electron microscopic analysis of light radioautographs. Science 197:1092-1094.

Kaplan MS, McNelly NA, Hinds JW (1985) Population dynamics of adult-formed granule neurons of the rat olfactory bulb. J Comp Neurol 239:117-125.

Katz LC, Shatz CJ (1996) Synaptic activity and the construction of cortical circuits. Science 274:1133-1138.

Kauer JS, White J (2001) Imaging and coding in the olfactory system. Annu Rev Neurosci 24:963-979.

Kirn J, Fishman Y, Sasportas K, Alvarez-Buylla A, Nottebohm F (1999) Fate of new neurons in adult canary high vocal center during the first 30 days after their formation. J Comp Neurol 411:487-494.

Kishi K (1987) Golgi studies on the development of granule cells of the rat olfactory bulb with reference to migration in the subependymal layer. J Comp Neurol 258:112-124.

Linden R (1994) The survival of developing neurons: a review of afferent control. Neuroscience 4:671-682.

Lois C, Alvarez-Buylla A (1994) Long-distance neuronal migration in the adult mammalian brain. Science 264:1145-1148.

Lois C, Garcia-Verdugo JM, Alvarez-Buylla A (1996) Chain migration of neuronal precursors. Science 271:978-981.

Luskin MB (1993) Restricted proliferation and migration of postnatally generated neurons derived from the forebrain subventricular zone. Neuron 11:173-189.

Menezes JRL, Smith CM, Nelson KC, Luskin MB (1995) The division of neuronal progenitor cells during migration in the neonatal mammalian forebrain. Mol Cell Neurosci 6:496-508.

Mori K, Shepherd GM (1994) Emerging principles of molecular signal processing by mitral/tufted cells in the olfactory bulb. Cell Biol 5:65-74.

Morshead CM, Van der Kooy D (1992) Postmitotic death is the fate of constitutively proliferating cells in the subependymal layer of the adult mouse brain. J Neurosci 12:249-256.

Morshead CM, Reynolds BA, Craig CG, McBurney MW, Staines WA, Morassutti D, Weiss S, Van der Kooy D (1994) Neural stem cells in the adult mammalian forebrain: a relatively quiescent subpopulation of subependymal cells. Neuron 13:1071-1082.

Najbauer J, Leon M (1995) Olfactory experience modulates apoptosis in the developing olfactory bulb. Brain Res 674:245-251.

Nakanishi S (1995) Second-order neurones and receptor mechanisms in visual- and olfactory-information processing. Trends Neurosci 18:359-364.

Oppenheim RW (1991) Cell death during development of the nervous system. Annu Rev Neurosci 14:453-501.

Pomeroy SL, LaMantia A-S, Purves D (1990) Postnatal construction of neural circuitry in the mouse olfactory bulb. J Neurosci 10:1952-1966.

Rosselli-Austin L, Williams J (1990) Enriched neonatal odor exposure leads to increased numbers of olfactory bulb mitral and granule cells. Dev Brain Res 51:135-137.

Sachse S, Galizia CG (2002) Role of inhibition for temporal and spatial odor representation in olfactory output neurons: a calcium imaging study. J Neurophysiol 87:1106-1117.

Shepherd GM (1972) Synaptic organization of the mammalian olfactory bulb. Physiol Rev 52:864-917.

Shipley MT, Ennis M (1996) Functional organization of olfactory system. J Neurobiol 30:123-176.

Verhage M, Maia AS, Plomp JJ, Brussaard AB, Heeroma JH, Vermeer H, Toonen RF, Hammer RE, van den Berg TK, Missler M, Geuze HJ, Sudhof TC (2000) Synaptic assembly of the brain in the absence of neurotransmitter secretion. Science 287:864-869.

Voyvodic JT (1996) Cell death in cortical development: How much? Why? So what? Neuron 16:693-696.

Wichterle H, Garcia-Verdugo JM, Alvarez-Buylla A (1997) Direct evidence for homotypic, glia-independent neuronal migration. Neuron 18:779-791.

Woolf TB, Shepherd GM, Greer CA (1991) Serial reconstructions of granule cell spines in the mammalian olfactory bulb. Synapse 7:181-192.

Yokoi M, Mori K, Nakanishi S (1995) Refinement of odor molecule tuning by dendrodendritic synaptic inhibition in the olfactory bulb. Proc Natl Acad Sci USA 92:3371-3375.

Zhao H, Reed RR (2001) X inactivation of the OCNC1 channel gene reveals a role for activity-dependent competition in the olfactory system. Cell 104:651-660.

Zheng C, Feinstein P, Bozza T, Rodriguez I, Mombaerts P (2000) Peripheral olfactory projections are differentially affected in mice deficient in a cyclic nucleotide-gated channel subunit. Neuron 26:81-91.

Ziv NE, Garner CC (2001) Principles of glutamatergic synapse formation: seeing the forest for the trees. Curr Opin Neurobiol 11:536-543. 